\title{
Suistalinable

\section{Augmented Leaching Pretreatments for Forest Wood Waste and Their Effect on Ash Composition and the Lignocellulosic Network}

Martin J. Taylor, * Hassan A. Alabdrabalameer, Apostolos K. Michopoulos, Roberto Volpe, and Vasiliki Skoulou*

Cite This: ACS Sustainable Chem. Eng. 2020, 8, 5674-5682

Read Online

ACCESS |

Џll Metrics \& More

Article Recommendations

Supporting Information

ABSTRACT: By augmenting conventional leaching technologies for the removal of ash constituents from lignocellulosic waste residues, a cleaner and energy efficient solution can be provided for critical industrial problems such as biomass feeding, defluidization, and reactor corrosion. It has been found that not only are inorganic constituents (ash) effectively removed by coupling a physicochemical technology with conventional leaching but also the intermolecular interactions within the lignocellulosic matrix can be modified, as shown by a variable crystallinity index (powder X-ray diffraction) without the loss of physical bonding (Fourier-transform

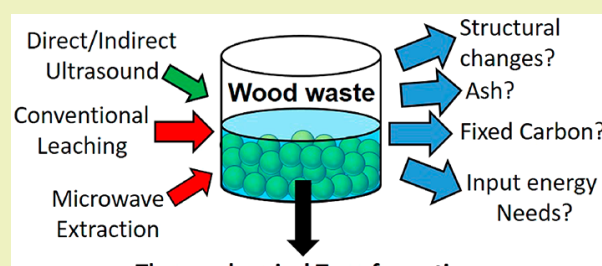

Thermochemical Transformation infrared spectroscopy). Ultimately, this allowed for a greater thermochemical transformation of cellulose, hemicellulose, and lignin for all technologies used: conventional leaching, indirect/directed ultrasound, and microwave irradiation. However, the use of directed ultrasound was found to be the standout, energy efficient technology $(8.6 \mathrm{~kJ} / \mathrm{g})$ to radically improve the thermochemical transformation of wood waste, especially in the reduction of fixed carbon at high temperatures. It was also found to be efficient at removing vital eutectic mixture causing elements, including $\mathrm{Si}$, which is known to be notoriously difficult to remove via leaching. In comparison, hot plate leaching and microwave irradiation use 39 and 116 times more energy, respectively. The integration of this technology into the energy production sector will prove vital in the future due to its scalability, as compared with microwave alternatives, which are currently not suitable for large scale operations. Additionally, the residence time required for directed ultrasound was found to be negligible as compared to the various other physicochemical techniques, $0.1 \mathrm{~h}$ opposed to $4 \mathrm{~h}$.

KEYWORDS: Biomass, Solid fuels, Energy assessment, Multiparameter analysis, Enhanced leaching processes, Waste-to-energy, Clean technology

\section{INTRODUCTION}

As the transition from fossil fuels commences to combat a climatological catastrophe, various alternate methods of energy production have been exploited such as solar, wind (on and offshore), nuclear, hydro, geothermal, and biorenewables. ${ }^{1-3}$ Globally, these alternate energy sources have been investigated in different ways. An example of such is the United Kingdom who in 2017 have switched their energy consumption mix to $31 \%$ renewables. However, of this percentage where natural gas and nuclear energy are dominant, only $9.4 \%$ is from biomass waste derived operations. ${ }^{4,5}$ This fraction is attributed to energy generated through thermochemical and biochemical methods such as combustion and gasification vs anaerobic digestion. ${ }^{6}$ This percentage is slightly higher than the overall global energy consumption of $9 \%$ for biomass waste derived processes. ${ }^{7}$ One of the major indicators for why very little biomass waste is used in comparison to other renewable technologies is the ash constituents present in the waste feedstock. This is variable depending on the type of lignocellulosic biomass waste used; wood based examples include pine, ${ }^{8}$ eucalyptus, ${ }^{9}$ oak, ${ }^{10}$ poplar, ${ }^{11}$ beech wood, ${ }^{12,13}$ or olive kernel wood. ${ }^{14}$ Other nonwood includes herbaceous wastes such as wheat straw, ${ }^{15}$ sugar cane straw, ${ }^{16}$ switchgrass, ${ }^{17}$ and bagasse. ${ }^{18}$

Between the two categories of lignocellulosic waste substrates, there is not only a difference in the hemicellulose/lignin ratio but also a stark difference in the inorganic elements present. ${ }^{19}$ Major elements generally found in the ash/ fly ash of decomposed lignocellulosic wastes are $\mathrm{K}, \mathrm{Na}, \mathrm{P}, \mathrm{Ca}$, $\mathrm{Mg}, \mathrm{S}, \mathrm{Cl}$, and $\mathrm{Si}^{4,20,21}$ Some of these are capable of catalyzing thermochemical gas phase reactions such as $\mathrm{K}, \mathrm{Na}, \mathrm{Ca}$, and $\mathrm{Fe}$ as well as the depolymerization of cellulose in low metal concentrations. $4,22-25$ There are many others that are instrumental in causing fluidized bed reactor agglomeration via eutectic mixtures; these compounds have lower melting points than standard oxide based materials. ${ }^{26}$ One of the most common problematic mixtures of parent ash constituents in biomass waste is $\mathrm{K}$ and $\mathrm{Si}$. These are present in the form of

Received: January 14, 2020

Revised: $\quad$ March 20, 2020

Published: March 24, 2020 
silica or silicates, attributed either from the inherent Si content of the waste substrate or from the reactor bed material, the usual culprit being cheap and readily abundant silica sand. ${ }^{20}$ Bed agglomeration is where the bed material grains have been fused together, restricting heat and mass transfer, ultimately preventing thermochemical conversion. This process leads to the restriction of the carrier/product gas through the system, ending in pressure instability leading to operational shut down. Not only will this cause the production of low carbon fuel to slow down or even stop, but also it can cause irreversible damage to the reactor itself. This can include erosion and corrosion to the heat exchanger surfaces of the reactor, ceramic filters of the gas cleaning system, turbine blades, and reactor walls due to slagging. ${ }^{20,26,27}$ High levels of $\mathrm{Cl}$ in the biomass waste feedstock will also lead to the production of $\mathrm{KCl}$ in the gas phase, which will react with $S$. This forms highly acidic sulfates on the reactor walls after cooling down or in cold spots in the reactor system. ${ }^{20,21}$ Often, these inorganic compounds will act as particulate traps where they will collect other gas phase contaminants, increasing the size of the slagging deposits. $^{20,21,27}$

In situ methods of mitigating problematic inorganic based compounds have been explored heavily in the literature. ${ }^{21,28}$ Initially, a lower reaction temperature can be used. This is where gasification takes place below $800{ }^{\circ} \mathrm{C}$ to avoid the formation of $\mathrm{K}$ and $\mathrm{Si}$ eutectic mixtures. ${ }^{4}$ However, this leads to a drop in both production and product selectivity as the gasification reactions are promoted at temperatures higher than $750{ }^{\circ} \mathrm{C} .{ }^{29}$ Various additives or bed material compositions can be used to alter aspects of the thermochemical reaction; this involves changing the product mix by varying the $\mathrm{H}_{2} / \mathrm{CO}$ ratio or via catalyzed transformations. Also, the heat balance, oxygen transport, or the ability to trap/react with inorganic based ash components is modified. ${ }^{24}$ However, in some cases, an enhanced oxygen mobility has been found to increase the concentration of $\mathrm{CO}_{2}$ found in the gas product mix. ${ }^{24}$ Examples of bed materials commonly used in fluidized bed systems are dolomite $\left(\mathrm{CaMg}\left(\mathrm{CO}_{3}\right)_{2}\right)$, bauxite $\left(\mathrm{Al}_{2} \mathrm{O}_{3} \cdot n \mathrm{H}_{2} \mathrm{O}\right)$, olivine $\left((\mathrm{Mg}, \mathrm{Fe})_{2} \mathrm{SiO}_{4}\right)$, and quartz sand $\left(\mathrm{SiO}_{2}\right){ }^{24,25,28,30,31}$ These compounds have had a large amount of success in lowering ash related problems, albeit presenting a new issue: a higher cost for industrial practice compared to plain silica (quartz) sand. For further justification of use, materials such as olivine, once they have been thermally processed in air, can be useful for tar cracking, ${ }^{24}$ whereas the inert material, quartz sand, is prone to forming eutectic mixtures with alkali ash constituents as mentioned previously.

An alternative, ex situ method of overcoming the buildup of inorganic compounds inside the reactor as well as negating the occurrence of bed agglomeration is to remove them from the waste feedstock prior to use. This can be efficiently carried out by leaching the waste substrate, often referred to industrially as washing. ${ }^{32,33}$ This technology has been used for coal pretreatments for a number of decades. ${ }^{34,35}$ Seen as a chemical pretreatment method, leaching is often carried out in demineralized water where the substrate is suspended and mixed. Over time, the liquid medium will diffuse into the feedstock's porous network and remove inorganic elements, forming a mineral rich leachate. As a result of this process being carried out, the internal lignocellulosic structure will swell. This causes an increase to the pore volume and available surface area. ${ }^{4}$ Previously, it has been found that temperatures up to $90{ }^{\circ} \mathrm{C}$ are effective at reducing the concentration of elements such as $\mathrm{S}, \mathrm{K}$, and $\mathrm{Cl}$ by up to $90 \% .^{36,37}$ However, when operating at high temperatures, organic aspects of the feedstock such as hemicellulose (sugars) will begin to be solubilized (a loss of valuable carbon units). Therefore, low temperature leaching is the preferred method of removing alkaline and alkali metals as well as is less energy intensive.

In this work, we will investigate the effect of conventional leaching of inorganic components from forest wood and how this process can be augmented by different technologies, without causing a detrimental effect to the carbon network in the form of bond breaking and the loss of potential fuel components. This will be carried out by combining the chemical pretreatment with various physicochemical technologies such as microwave irradiation, previously used for extracting metals from ores, ${ }^{38}$ and directed/indirect ultrasound, used in the past for leaching sugars and proteins from biomass. $^{39}$ Additionally, the surface and bulk substrate structure will be analyzed to determine the full effect of the leaching process on the lignocellulosic waste material via inductively coupled plasma optical emission spectroscopy (ICP-OES), powder X-ray diffraction (PXRD), Fouriertransform infrared spectroscopy (FTIR), scanning electron microscopy (SEM), and thermogravimetric analysis (TGA). Moreover, an analysis on the energy consumption of each technology has been carried out in order to assess the amount of energy consumed to pretreat the lignocellulosic waste. Conclusions can then be drawn to determine the least energy intensive pretreatment method. The technologies and assessment reported in this work may be applicable in the future to low carbon energy generation. Finally and in order to evaluate the overall performance of the alternative examined pretreatment technologies, a multiparameter assessment based on six selected indicators was carried out. All of which are of high importance and need to be taken into consideration for energy from waste investors interested in low carbon footprint energy generation.

\section{MATERIALS AND METHODS}

Raw forest wood waste, all taken from the same source (locally sourced pine), was physically pretreated using a Retsch GM200 Grindomix Knife Mill followed by sieving fractions of the desired particle size $(<250 \mu \mathrm{m})$ using a Retsch AS200 Vibratory Sieve Shaker. The ultimate $(\mathrm{C}, \mathrm{H}, \mathrm{N}, \mathrm{S}$, and calculated $\mathrm{O}$ content) and proximate analysis (moisture and volatile content) as well as the higher heating value, HHV, is reported in Table 1. For all data acquired, the process was carried out in triplicate to account for potential feedstock variability. The ultimate analysis of the forest wood was carried out using a Fisons Instruments EA 1108 CHNS elemental analyzer; sample sizes for this characterization were between 2 and $3 \mathrm{mg}$, and the elemental composition was to found to be similar across 3 different samples. From this data, there was only a broad variation in nitrogen content. The ash component was measured by heating $1 \mathrm{~g}$ of untreated wood waste in a muffle furnace (Carbolite AAF 11/3 ashing furnace, in air). Here, the material was heated at $10{ }^{\circ} \mathrm{C} / \mathrm{min}$ and held for $2 \mathrm{~h}$ at $600{ }^{\circ} \mathrm{C}$. The proximate analysis took place under thermogravimetric (PerkinElmer TGA4000) conditions under a $\mathrm{N}_{2}$ flow where moisture and devolatilization were measured in triplicate. The proximate analysis thermal method used was as follows: $30-105$ ${ }^{\circ} \mathrm{C}\left(5^{\circ} \mathrm{C} / \mathrm{min}\right.$, held $\left.0.3 \mathrm{~h}\right), 100-600{ }^{\circ} \mathrm{C}\left(10^{\circ} \mathrm{C} / \mathrm{min}\right.$, held $\left.0.5 \mathrm{~h}\right)$, and $600-900{ }^{\circ} \mathrm{C}\left(10^{\circ} \mathrm{C} / \mathrm{min}\right.$, held $\left.0.3 \mathrm{~h}\right)$. Fixed carbon was calculated by using the ash content acquired from the muffle furnace approach (eq S1). The inorganic content of the raw and pretreated forest wood was determined by inductively coupled plasma optical emission spectroscopy (ICP-OES, Thermo Fisher 7400). The samples were digested via microwave irradiation (CEM Discover-S microwave system) in 4 
Table 1. Averaged Ultimate and Proximate Analysis of the Untreated Wood Waste

\begin{tabular}{|c|c|}
\hline \multicolumn{2}{|c|}{$\begin{array}{l}\text { Untreated Forest Wood } \\
\text { ultimate analysis (average wt \%, dry basis) }\end{array}$} \\
\hline carbon & $48.19 \pm 0.57$ \\
\hline oxygen $^{a}$ & $44.73 \pm 0.15$ \\
\hline hydrogen & $6.35 \pm 0.03$ \\
\hline nitrogen & $0.48 \pm 0.31$ \\
\hline sulfur & $0.00 \pm 0.01$ \\
\hline ash & $0.74 \pm 0.11$ \\
\hline \multicolumn{2}{|c|}{ proximate analysis (average wt $\%$, dry basis) } \\
\hline moisture & $5.5 \pm 1.14$ \\
\hline volatiles & $76.5 \pm 0.93$ \\
\hline fixed carbon & $17.3 \pm 0.38$ \\
\hline HHV (MJ/kg) & $17.5 \pm 0.41$ \\
\hline Calculated by th & \\
\hline
\end{tabular}

$\mathrm{mL}$ of $\mathrm{HNO}_{3}$ (Romil SPA grade $70 \%$ ) at $200{ }^{\circ} \mathrm{C}$, followed by aqueous dilution. Bulk compositions were measured to be $\pm 10-20 \%$, dependent on element response. FTIR spectra were obtained using a Thermo Scientific Nicolet iS5 with a PIKE MIRacle single reflection horizontal ATR accessory. Scanning electron microscope (SEM) images were acquired via a Zeiss EVO 60 instrument at a pressure of $10^{-2} \mathrm{~Pa}$ and an electron acceleration voltage of $20 \mathrm{kV}$. Powders were adhered to a coated conductive carbon tape and attached to the specimen holder, where a $10 \mathrm{~nm}$ thick coating of graphite was added to the surface. The crystallinity of the cellulose component was monitored via powder X-ray diffraction (PXRD) measurements using monochromated $\mathrm{Cu} \mathrm{K} \alpha$ radiation $(\lambda=0.1542 \mathrm{~nm})$ on a PANalytical Empyrean series 2 diffractometer. Subsequent analysis of the diffractograms was performed in HighScore Plus (2013, PANalytical B.V.) with the ICDD's PDF-2 2012 database. The energy (electricity) consumed per experiment has been measured with the aid of a Brennenstuhl PM231 LCD Plug in Energy Meter.

Augmented Pretreatment Technologies. Individual samples of finely milled pine wood were immersed in deionized water $(10 \mathrm{~g} /$ $\mathrm{L}$ ) and subjected to various methods of physicochemical pretreatment to extract ash constituents. The technologies used were conventional hot plate leaching at $45{ }^{\circ} \mathrm{C}$ and $700 \mathrm{rpm}$ (to disrupt the surface tension of the water and homogenize the process) for 2,4 , and $24 \mathrm{~h}$ (Heidolph Hei-Tec hot plate). The broad variation in leaching time was carried out due to elements such as $\mathrm{S}, \mathrm{P}, \mathrm{Mg}$, and Fe possessing a higher solubility in water value. ${ }^{4}$ This means that a longer extraction time is required to maximize removal. Indirect ultrasound (SLS U300) was used where the forest wood waste was suspended in water inside a glass beaker. The vessel was then placed on the base of the unit, and the sweeping action of the device was carried out over 2, 3, and $4 \mathrm{~h}$ periods. Directed ultrasound utilized a Branson Digital Sonifer 450 operating at $25 \%$ amplitude at a depth of $75 \%$ into the conical sample holder. This was where the probe underwent a number of cycles, pulsing for $20 \mathrm{~s}$ and resting for $20 \mathrm{~s}$. Total residence times completed were 2, 4, and $6 \mathrm{~min}$. Residence time was limited for this technology to reduce chances of potential sample degradation. Finally, microwave irradiation was carried out using an Ethos EX MicrowaveAssisted Extraction System, $1200 \mathrm{~W}$ with a rotary vessel reactor system over 2, 3, and $4 \mathrm{~h}$, operating with an output of $500 \mathrm{~W}$. An above ambient temperature $\left(45^{\circ} \mathrm{C}\right)$ was used so that microwave extraction could be viable. This temperature was used for all technologies with the exception of directed ultrasound; this occurred at room temperature. Upon leaching completion for all technologies, the forest wood was separated from the leachate via vacuum filtration and subsequently dried in a Memmert UN75 circulating oven at 105 ${ }^{\circ} \mathrm{C}$ for $24 \mathrm{~h}$.

Thermal Degradation Measurements. The effect of pretreatment on the rate of thermal decomposition, moisture, volatile, and fixed carbon and ash content was monitored by thermogravimetric analysis using a PerkinElmer TGA4000 under a nitrogen flow at 30 $\mathrm{mL} / \mathrm{min}$. This was carried out using a stepwise heating profile, starting at $30-105{ }^{\circ} \mathrm{C}\left(5{ }^{\circ} \mathrm{C} / \mathrm{min}\right)$, held for $10 \mathrm{~min}$ at $105^{\circ} \mathrm{C}, 105-600{ }^{\circ} \mathrm{C}$ $\left(10{ }^{\circ} \mathrm{C} / \mathrm{min}\right)$, and held for $20 \mathrm{~min}$ at $600{ }^{\circ} \mathrm{C}$ and $600-900{ }^{\circ} \mathrm{C}(10$ ${ }^{\circ} \mathrm{C} / \mathrm{min}$ ), where it was held finally for $20 \mathrm{~min}$.

\section{RESULTS AND DISCUSSION}

After pretreatment, the substrates underwent ICP-OES where a broad array of elements were followed such as $\mathrm{Ca}, \mathrm{Fe}, \mathrm{K}, \mathrm{Mg}$, $\mathrm{Na}, \mathrm{P}, \mathrm{S}$, and $\mathrm{Si}$. Figure $\mathrm{S} 1 \mathrm{a}-\mathrm{d}$ shows the effect of the augmented leaching technologies over time. Table 2 presents the overall element extraction at the maximum time monitored. Here, it is shown that all technologies facilitate an ash removal of over $66 \%$. It also shows that the conventional hot plate and microwave have similar capabilities for overall inorganic reduction of $77.9 \%$ and $77.3 \%$, respectively. However, the specific elements removed from each method are highly variable, depending on the technology used and for how long. For elements with a high water solubility, e.g., $\mathrm{Na}, \mathrm{K}$, and $\mathrm{P}$, the levels of extraction are similar for all technologies, where as shown in Figure $\mathrm{S} 1 \mathrm{a}-\mathrm{d}$, there is no benefit from a prolonged leaching pretreatment. All technologies were also efficient in the removal of $\mathrm{Ca}$ from the waste wood, a highly abundant element in softwood. ${ }^{40}$ It was found that both forms of ultrasound pretreatments retarded the extraction of $\mathrm{Ca}$ marginally over time, proving to be $10 \%$ less effective than the conventional hot plate, as shown in Figure S1. There is a clear advantage to the use of directed ultrasound for the removal of the often troublesome or tricky to extract elements $\mathrm{Fe}, \mathrm{S}$, and $\mathrm{Si}$. Specifically, the high intensity directed ultrasound was able to extract $75 \%$ of the Si component during a short residence time of $6 \mathrm{~min}$. Microwave irradiation was also found to remove $\mathrm{Si}$, albeit it was $37.5 \%$ after $4 \mathrm{~h}$. It has been documented in the past that Si removal from biomass waste is notoriously difficult, requiring high leaching temperatures for only partial removal. ${ }^{41}$ This is the reason why after $24 \mathrm{~h}$ of continuous hot plate leaching under mild conditions there was no detectable decrease in $\mathrm{Si}$ concentration (Table 2). For $\mathrm{Fe}$, the directed ultrasound probe was found to remove $72.7 \%$ after $2 \mathrm{~min}$ (Figure S1d);

Table 2. Summary ICP-OES Data Showing the Effect of Conventional and Enhanced Leaching of Softwood Waste at the Maximum Residence Time Investigated ${ }^{a}$

\begin{tabular}{|c|c|c|c|c|c|c|c|c|c|c|}
\hline \multirow[b]{2}{*}{ technology } & \multirow[b]{2}{*}{ pretreatment time $(\mathrm{h})$} & \multirow[b]{2}{*}{ inorganic reduction (\%) } & \multicolumn{8}{|c|}{ element removal from raw wood waste (\%) } \\
\hline & & & $\mathrm{Ca}$ & $\mathrm{Fe}$ & $\mathrm{K}$ & $\mathrm{Mg}$ & $\mathrm{Na}$ & $\mathrm{P}$ & $S$ & $\mathrm{Si}$ \\
\hline conventional hot plate & 24.0 & 77.9 & 76.3 & 54.5 & 96.9 & 81.8 & $\mathrm{~N} / \mathrm{A}$ & $\mathrm{N} / \mathrm{A}$ & 41.7 & $\mathrm{~N} / \mathrm{A}$ \\
\hline directed ultrasound & 0.1 & 76.3 & 76.3 & 72.7 & 96.9 & 77.3 & $\mathrm{~N} / \mathrm{A}$ & $\mathrm{N} / \mathrm{A}$ & 75.0 & 75.0 \\
\hline indirect ultrasound & 4.0 & 66.0 & 66.4 & N/A & 93.8 & 68.2 & $\mathrm{~N} / \mathrm{A}$ & $\mathrm{N} / \mathrm{A}$ & 75.0 & $\mathrm{~N} / \mathrm{A}$ \\
\hline microwave & 4.0 & 77.3 & 73.3 & 54.5 & 95.8 & 81.8 & $\mathrm{~N} / \mathrm{A}$ & $\mathrm{N} / \mathrm{A}$ & 83.3 & 37.5 \\
\hline
\end{tabular}

${ }^{a} \mathrm{~N} / \mathrm{A}$ represents a value below the detection limit. 
for this element, the maximum Fe was removed after a short residence time as the prolonged pretreatment had no further effect. For the conventional hot plate and microwave irradiation, the removal of $\mathrm{Fe}$ from the wood waste is time dependent (Figure S1a,c), resulting in the same level of extraction after $4 \mathrm{~h}$ (microwave) and $24 \mathrm{~h}$ (conventional hot plate). For this element as well as $\mathrm{Si}$, the indirect ultrasound technology was not appropriate, presenting no detectable decrease after $4 \mathrm{~h}$ of sustained operation. Interestingly, ultrasound as a physicochemical technology reduced $S$ by the same magnitude after $4 \mathrm{~h}$ (indirect) and $6 \mathrm{~min}$ (directed); both were more effective than conventional leaching but marginally less effective than microwave augmented extraction.

Ultimately, the data presented in Table 2 show that, as a technology, the sweeping action of indirect ultrasound is not an effective method of enhancing leaching. However, by directing the ultrasound into the substrate in short cycles, it is very effective. Not only is this favorable due to a short residence time, but also it was found to be more efficient than a conventional hot plate or indirect ultrasound, in terms of $S$ and Si removal.

Although a prolonged residence time for the augmented leaching technologies was not essential for all the monitored elements (Figure $\mathrm{S} 1 \mathrm{a}-\mathrm{d}$ ), the lignocellosic network does appear to be affected over time, namely, the crystalline region of cellulose. This is where the glucose monomers of the cellulose are connected by glycosidic linkages as well as intermolecular interactions such as hydrogen bonding. Such arrangements present areas of high ordering known as crystalline, whereas regions where there is limited ordering are known as amorphous. The benefit of reducing the crystallinity of the cellulose is that less energy could be required to thermally decompose the biomass waste, compared to if it is not pretreated. ${ }^{42}$ However, a downside to lowering the crystallinity of cellulose is that the solubility of the substrate in water increases. ${ }^{43}$ This means that carbon content could be lost from the feedstock into the leachate. The crystallinity index $(\mathrm{Crl})$ of the raw/pretreated wood substrates can be calculated as a percentage by monitoring the loss in peak intensity for the crystalline cellulose (002) feature via PXRD. This is then used as part of Segal et al.'s equation shown in eq $1 .{ }^{44}$

$$
C I \%=\left(\frac{I(002)-I(A M)}{I(002)}\right) \times 100
$$

Figure 1 shows an arrangement of PXRD diffractograms observing the effect of the pretreatment technology on the Crl; this was calculated by componentizing the peaks to determine the amorphous and crystalline regions. ${ }^{44,45}$ Figure S2 shows a fitted diffraction pattern once the background had been subtracted. Table 3 shows that prior to any pretreatments the inherent $\mathrm{Crl}$ of the untreated wood waste is $82.1 \%$. Figure 1 shows that the indirect ultrasound pretreatment, although efficient for the removal of sulfur (Table 2 and Figure S1b), is not an effective technology at reducing the crystallinity index of the wood waste. This value after $4 \mathrm{~h}$ as reported in Table 3 is $77.5 \%$; this is a drop of $4.6 \%$ from the untreated wood. Table 3 does clearly show that a decrease in $\mathrm{Crl}$ is directly related to the residence time of each augmented biomass waste pretreatment technology. For all the technologies operated up to $4 \mathrm{~h}$, hot plate, microwave, and indirect ultrasound, the calculated $\mathrm{Crl}$ values were $74.5 \%, 69.5 \%$, and $77.5 \%$,

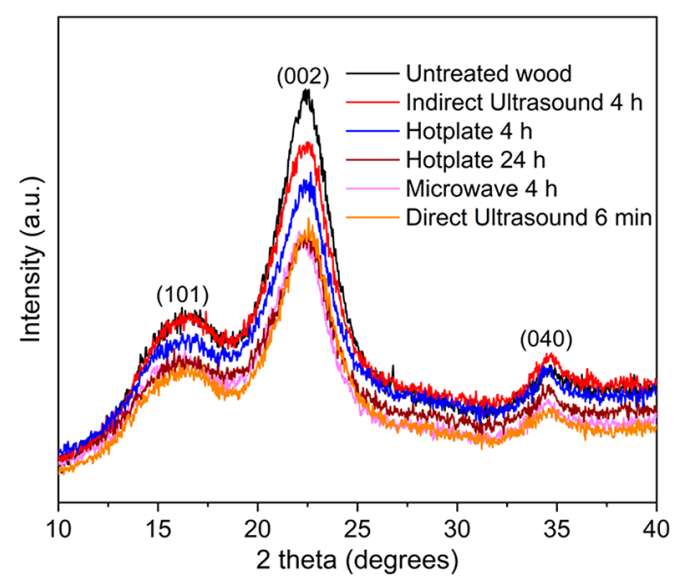

Figure 1. Stacked PXRD diffractograms of untreated and pretreated wood waste showing the effect of the augmented technology on the Crl.

Table 3. Effect of the Leaching Technology on the Cellulose Crystallinity over Time ${ }^{a}$

\begin{tabular}{llc}
\multicolumn{1}{c}{ technology } & time & $\mathrm{Crl}(\%)$ \\
untreated wood & & 82.1 \\
conventional hot plate & $2 \mathrm{~h}$ & 75.0 \\
conventional hot plate & $4 \mathrm{~h}$ & 74.5 \\
conventional hot plate & $24 \mathrm{~h}$ & 68.2 \\
directed ultrasound & $2 \mathrm{~min}$ & 74.2 \\
directed ultrasound & $4 \mathrm{~min}$ & 72.7 \\
directed ultrasound & $6 \mathrm{~min}$ & 70.9 \\
indirect ultrasound & $2 \mathrm{~h}$ & 78.6 \\
indirect ultrasound & $3 \mathrm{~h}$ & 78.1 \\
indirect ultrasound & $4 \mathrm{~h}$ & 77.5 \\
microwave & $2 \mathrm{~h}$ & 79.4 \\
microwave & $3 \mathrm{~h}$ & 77.5 \\
microwave & $4 \mathrm{~h}$ & 69.5 \\
\hline
\end{tabular}

${ }^{a} \mathrm{Crl}$ : crystallinity index.

respectively. This shows that the microwave was the most effective method of reducing the crystallinity of cellulose. However, the directed ultrasound probe in terms of residence time requirements proved to be the most effective for disrupting the intermolecular interactions within the cellulose network. Diffraction patterns of all pretreatment technologies used across all residence times are presented in Figure S3a-d.

Bonding of the organic matrix was observed by FTIR; here, depending on the features in the spectra, various functional groups can be assigned. Unlike PXRD, this technique does not just consider cellulose features.

This means that each pretreated biomass waste material can be scrutinized for its lignin and hemicellulose bonding as well as bonding to the cellulose component.

Figure 2 shows an arrangement of FTIR spectra for the untreated wood and all of the pretreated substrates investigated at the maximum residence time used. The assignment of each band is in a very close proximity to various other data presented in the literature. ${ }^{46,47}$ The first band, starting from the lowest wavenumber and working upward, is $1032 \mathrm{~cm}^{-1}$, which is attributed to $\mathrm{C}-\mathrm{O}, \mathrm{C}=\mathrm{C}$, and $\mathrm{C}-\mathrm{C}-\mathrm{O}$ stretching for cellulose, hemicellulose, and lignin. The stretch at $1162 \mathrm{~cm}^{-1}$ is assigned to an asymmetrical $\mathrm{C}-\mathrm{O}-\mathrm{C}$ for cellulose and hemicellulose. An aromatic ring vibration specific to guaiacyl alcohol, one of the molecules indicative of lignin, 


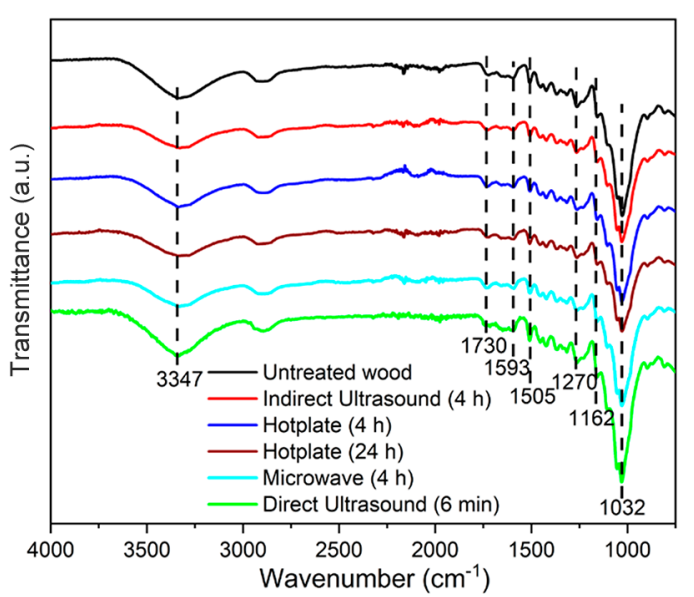

Figure 2. Overlaid FTIR spectra of untreated and pretreated wood waste; dashed lines indicate various cellulose, lignin, and hemicellulose functional groups.

was seen at $1270 \mathrm{~cm}^{-1} \cdot 4,46,47$ However, there was no band observed $\sim 1327 \mathrm{~cm}^{-1}$ for syringyl alcohol, another fingerprint of lignin. ${ }^{46}$ This is because syringyl alcohol is specific to hardwood; the data suggests that this forest wood waste belongs in fact to the softwood family, indicating the subtle differences of woody biomass waste species. The terms hard and soft are not typecast to the material's tensile strength as the name would suggest. Instead, hardwood is typically from broad leaved trees, e.g., eucalyptus, ${ }^{48}$ whereas softwood is generally sourced from trees without these leaves such as pine, the feedstock used for this work. ${ }^{48}$ Other lignin specific aromatic ring vibrations were isolated at 1505 and 1593 $\mathrm{cm}^{-1}$. ${ }^{49}$ The band at $1730 \mathrm{~cm}^{-1}$ highlighted in Figure 2 has been identified as a ketone/aldehyde $\mathrm{C}=\mathrm{O}$ stretch for hemicellulose. $^{47,49}$ Finally, the broad $\mathrm{O}-\mathrm{H}$ stretch at 3347 $\mathrm{cm}^{-1}$ is attributed specifically to a softwood band position for lignin; this shifts to a higher wavenumber $\left(3421 \mathrm{~cm}^{-1}\right)$ for hardwood. $^{46,47}$

The take home message from these spectra are that all of the features present in the untreated wood waste are identifiable in every pretreated sample. This infers that the various pretreatment technologies irrelevant of residence time are not removing hemicellulose or lignin features; therefore, chemical bonding remains unchanged, and there is no obvious change to the carbon content postleaching.

Figure 3 shows an array of high resolution SEM images in the order of the least to most destructive augmented technology. Figure 3A shows the surface structure of the untreated wood; well ordered channels are clearly shown with no obvious fracturing. Figure $3 \mathrm{~B}$ is the first of the pretreated samples, indirect ultrasound after $4 \mathrm{~h}$. This has shown that there has been a pressure build up within the lignocellulosic waste causing stomata like structures to form, suggesting that the cell wall of the wood has begun to burst open (yellow circle). Above these surface alterations, there are also signs of cracking along the channel with some slight separation (yellow square). Interestingly, the indirect ultrasound technology was found to have a negligible effect on the Crl (Figure 1, Table 3); it could mean that the technology is surface specific. The indirect ultrasound technology operates in a sweeping motion; this had a dampened effect as the substrate suspension was housed in a glass beaker, and this means that the energy traveling across the device will be diminished at the center of the sample holder. Figure $3 \mathrm{C}$ shows the effect of microwave irradiation on the softwood material. Although at a higher magnification than the other images presented, there is a greater surface destructive effect (red square) as compared with indirect ultrasound, as well as an increase in the number of "stomata" (blue circle). For this technology, the sample is heated from the inside out. It appears that, as pressure has built up, the cell wall has ruptured, and as a result, there is buildup of wood around the center of the stomata structure, similar to a volcanic eruption. There is also more evident substrate separation for this technology, as the once ordered channels have fractured. This technology alongside conventional hot plate leaching over $24 \mathrm{~h}$ and directed ultrasound at $6 \mathrm{~min}$, Figure 3D,E, respectively, presents $\mathrm{Crl}$ values similar to one another (Table 3). Figure 3D, although operating at a far higher residence time than the other technologies, presents a more distorted surface morphology as compared with Figure
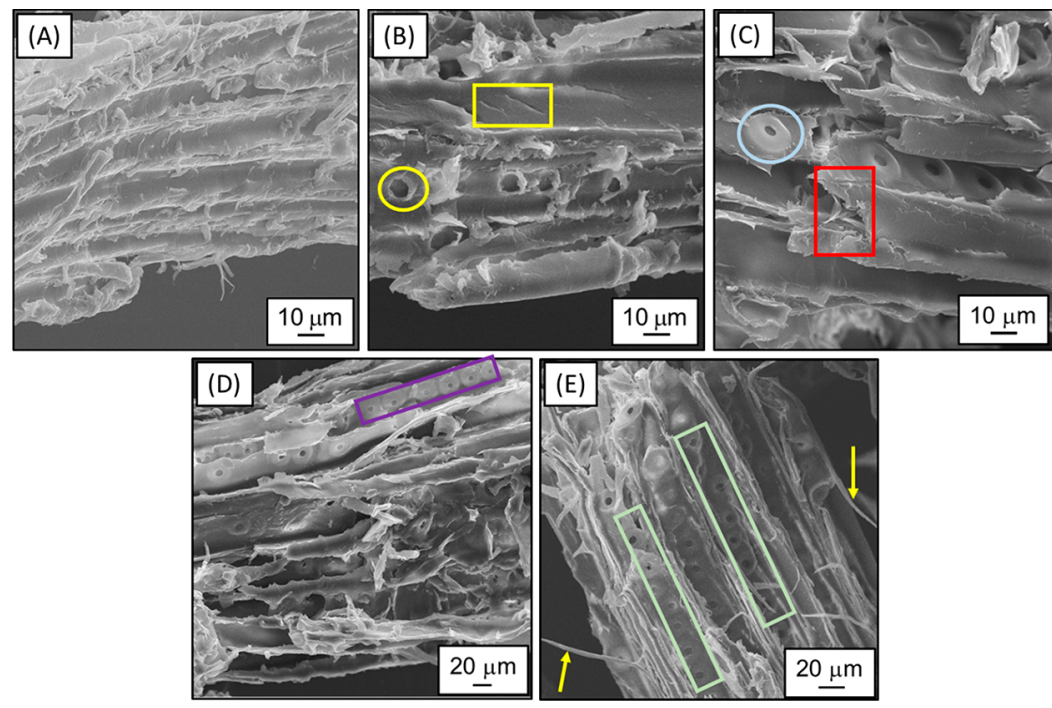

Figure 3. SEM images of untreated and pretreated wood waste: (A) untreated wood waste, (B) indirect ultrasound after $4 \mathrm{~h}$, (C) microwave irradiation after $4 \mathrm{~h}$, (D) conventional hot plate stirring after $24 \mathrm{~h}$, and (E) directed ultrasound after 6 min. 
3A. Here, the ordered channels have been warped and fractured causing surface splintering. There is also a substantial stomata concentration along a number of the channels (purple square). However, this pales in comparison to the effect of directed ultrasound pulsed over a $6 \mathrm{~min}$ period (Figure 3E). The effect of this technology appears to have less of an effect on the surface morphology in terms of channel fracturing and splintering, and it has had a notable effect on stomata concentration (green squares). The ordered channels have been saturated by micron sized ruptures; this concludes that there has been a substantial pressure buildup within the cell wall causing it to burst. There is also the presence of microfibrils (yellow arrows), which suggests that the cellulose has undergone deterioration of the cell wall. ${ }^{50}$ This is not obvious in Figure $3 \mathrm{~B}-\mathrm{D}$; as a result, this aspect of surface manipulation could be specific to directed ultrasound under the conditions used.

Figure 4 illustrates the electrical energy consumption normalized per gram of wood waste for each pretreatment

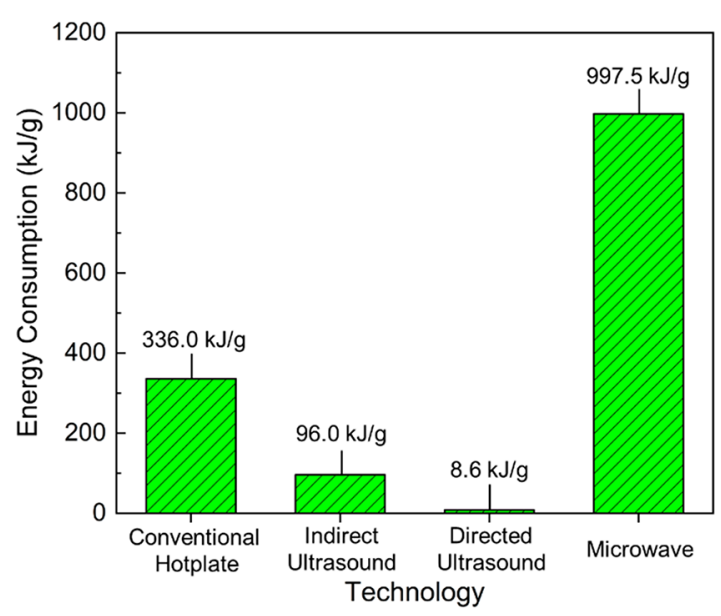

Figure 4. Energy consumption per gram of wood waste for each examined pretreatment technology.

technology assessed in this work. These results indicate that the most energy intensive pretreatment technology is the microwave $(997.5 \mathrm{~kJ} / \mathrm{g}$ ), followed by the conventional hot plate $(336.0 \mathrm{~kJ} / \mathrm{g})$, indirect ultrasound $(96.0 \mathrm{~kJ} / \mathrm{g})$, and finally directed ultrasound $(8.6 \mathrm{~kJ} / \mathrm{g})$. By directing the ultrasound output to a single point (directed ultrasound), the energy output is substantially decreased. This infers that directed ultrasound used $2.56 \%$ of the energy used for the conventional leaching. When the ultrasound technologies were compared, indirect ultrasound consumed more than 11 times the energy than the directed equivalent.

Microwave assisted leaching is an energy intensive process as the power consumed during the initial heating process is incredibly high. When at the leaching temperature, the system pulses periodically to maintain the temperature; energy is however used for sample rotation to ensure homogeneous heating, and during nonpulse periods, this energy is wasted. The electricity requirements of the microwave technology leads to almost 116 times more energy consumed, as compared to the directed ultrasound. This means that the directed ultrasound pretreated is the most energy efficient method. Thermochemical reactions were carried out under TGA conditions in flowing $\mathrm{N}_{2}$. By utilizing a single heating ramp rate $\left(20^{\circ} \mathrm{C} / \mathrm{min}\right)$ during the temperature range of $100-400$
${ }^{\circ} \mathrm{C}$, the light volatile molecules derived from the cellulose and hemicellulose components are released. ${ }^{51}$ At a higher temperature of $600{ }^{\circ} \mathrm{C}$, lignin components in the form of heavy volatiles are then decomposed. Figure $5 \mathrm{~A}$ provides an
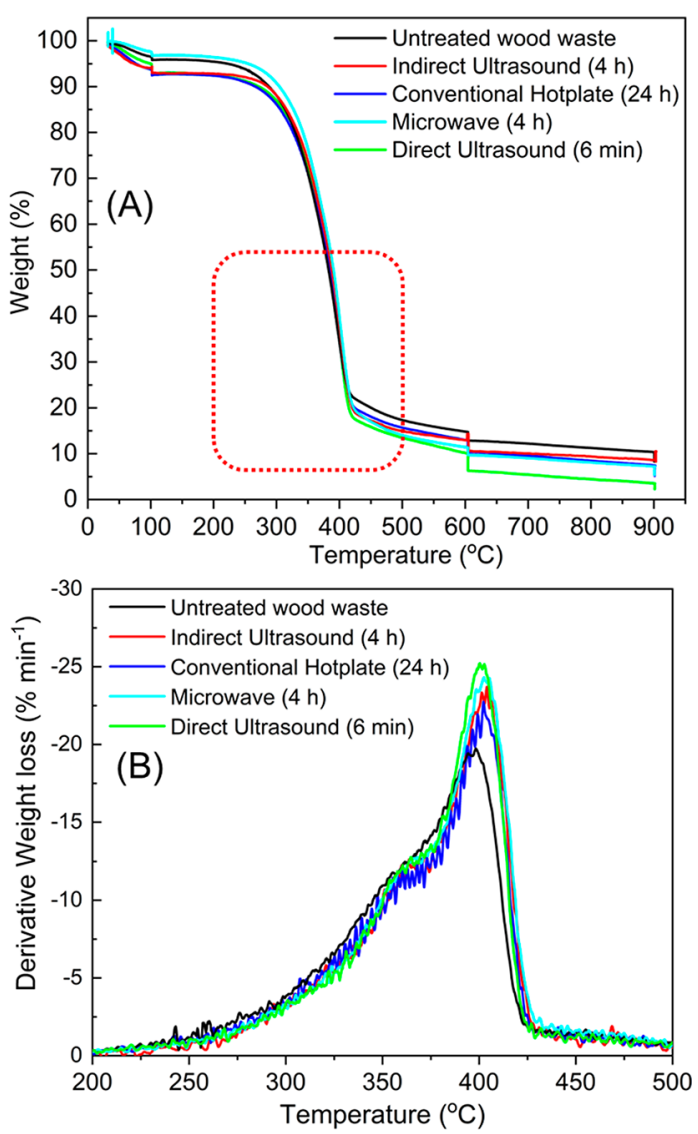

Figure 5. Thermogravimetric analysis under $\mathrm{N}_{2}$ across all technologies at the maximum residence time, where (A) is an overview of the reaction profile and (B) presents the derivative weight loss profile, highlighted by a red dashed square in (A).

illustration of the overall reaction profile when the moisture is released from the sample at $100{ }^{\circ} \mathrm{C}$. This is variable for each of the samples, as all of the pretreated biomass waste, with the exception of the microwave pretreatment, have a lower moisture content as compared to the raw wood waste. The reaction profile for volatiles released is identical for all materials up to $\sim 400{ }^{\circ} \mathrm{C}$. This means that the energy required for the second stage of the process to be carried out has not changed. This therefore infers that the pretreatment processes used are not dramatically altering the lignocellulosic matrix, albeit each affecting the $\mathrm{Crl}$ and surface morphology. Instead, due to the subtle differences in the weight loss \% per min observed in Figure 5B, it can be suggested that there has been substantial disruption to the intermolecular interactions within the lignocellulosic matrix, agreeing with the decreases in $\mathrm{Crl}$ (Table 3). For the case of directed ultrasound as a pretreatment technology, the highest rate of sample weight loss $\%$ is observed (Figure 5B); Figure 5A also shows that less fixed carbon remains. This is represented by a $51 \%$ decrease in sample weight at $600{ }^{\circ} \mathrm{C}$ when compared with untreated wood. However, for the other three technologies used, the decrease in weight (\%) at this temperature is very similar at $\sim 24 \%$. This means that the directed ultrasound has also disrupted the 
Table 4. Results of the Multiparameter Assessment of the Conventional and Alternative Biomass Waste Pretreatment Technologies on the Leaching of Softwood Waste

\begin{tabular}{|c|c|c|c|c|c|c|c|}
\hline \multirow[b]{2}{*}{ technology } & \multirow[b]{2}{*}{ pretreament time } & \multirow[b]{2}{*}{ inorganic reduction } & \multicolumn{2}{|c|}{$\begin{array}{l}\text { element removal from } \\
\text { raw wood waste }\end{array}$} & \multirow[b]{2}{*}{ crystallinity } & \multirow[b]{2}{*}{ energy consumption } & \multirow[b]{2}{*}{ average $^{a}$} \\
\hline & & & $S$ & $\mathrm{Si}$ & & & \\
\hline conventional hot plate & 240.00 & 1.00 & 0.50 & 0.00 & 1.00 & 39.07 & 46.93 \\
\hline directed ultrasound & 1.00 & 0.98 & 0.90 & 1.00 & 1.04 & 1.00 & 0.99 \\
\hline indirect ultrasound & 40.00 & 0.85 & 0.90 & 0.00 & 1.14 & 11.16 & 9.01 \\
\hline microwave & 40.00 & 0.99 & 1.00 & 0.50 & 1.02 & 115.99 & 26.58 \\
\hline
\end{tabular}

lignin interaction within the matrix, without removing any of the chemical bonding, as seen in Figure 2.

The conventional and enhanced leaching technologies used in this work were assessed for their large scale feasibility using six characteristic indicators; these represent their equal physical parameters, respectively. The indicators have been presented and analytically discussed previously in the manuscript. The first gauge is the required pretreatment time; in industrial applications, the pretreatment time should be minimum in order to ensure continuous feed rates, reducing feedstock storage, and processing areas (logistics). The following three characteristics deal with the capability of the technology to extract inorganic components, expressed as inorganic reduction efficiency (IRF) and the removal of sulfur and silicon constituents. The IRF expresses the percentage of the inorganic elements that are extracted from the waste solid matrix. The IRF criterion should be maximized in order to minimize potential operational issues such as corrosion phenomena and sulfur based emissions as well as eutectic mixture creation and related defluidization events. ${ }^{4,41}$ The last two characteristics taken into consideration are the crystallinity index and the energy consumption required for the pretreatment technology. The crystallinity index in our case expresses the easiness of thermochemical decomposition. The lower the crystallinity of the carbonaceous matrix, the less energy is required for thermal decomposition of the improved solid fuel. The energy consumed during the pretreatment process of the biomass waste should be a minima to offset the energy production, improving the cost-effective nature of both the solid fuel and production process; this is imperative for the waste-to-energy generation industry.

These characteristic indicators have been translated into quantitative key factors by dividing each parameter with the minimum or maximum counterpart, deducing the best performing technology per criteria mentioned previously; thus, a key factor equal to 1.0 indicates the best performance. Values of the key factor above $(>1)$ or below $(<1)$ this represent the time discrepancy of the best performing characteristic indicators that should be minimized and maximized, respectively. Table 4 summarizes the quantitative key factors per parameter and their average value. More specifically, the ultrasound technologies are both promising as these leaching enhancements have the lowest average value. In contrast, microwave and conventional hot plate technologies are the most inefficient, as their average value is 26.5 and 47 times higher than directed ultrasound, the best performing technology, respectively. In addition, it is interesting that the directed ultrasound technology achieves an average value of 0.99 , indicating only $0.01 \%$ discrepancy from the best performance limit. This is due to the fact that the directed ultrasound technology achieves the lowest pretreatment time and energy consumption factors, compared to the competitive alternatives such as conventional hot plate and microwave.

\section{CONCLUSIONS}

Industrial scale low carbon energy generation based on woody waste should demonstrate an efficient, stable, and nonproblematic long-term operation. When alternative solid fuels such as woody wastes are exploited in the fluidized bed reactors, initial physical pretreatments to increase the surface area/volume ratio are necessary requirements.

Variations in the pretreatment used can be tailored to meet the required specifications (e.g., feeding capabilities, elemental composition, particle size, and moisture content). The pretreatment of pine wood waste was carried out using augmented leaching techniques. This is where a mild temperature of $45^{\circ} \mathrm{C}$ was used in the presence of conventional stirring, microwave irradiation, and indirect ultrasound. Directed ultrasound was also carried out in the absence of water heating. The pretreated wood was found to contain dramatically less inorganic components across all technologies (>66\%). However, extended residence times for all techniques was not required for inorganic extraction; it was proved that the reduction in ash constituents reached a maxima at the first time point. This is due in part to the elemental solubility in water. This is the reason why the reduction in $S$ is dependent on time (high solubility in water), even for the directed ultrasound technology. Directed ultrasound was also the only enhanced leaching technology that could effectively remove Si. As well as ash component removal, there has been varying differences to the structure and surface morphology of the substrate. It was found that the crystallinity index decreased in direct relation to residence time for every technology. The maximum decrease of $\sim 13 \%$ was observed for the conventional hot plate $(24 \mathrm{~h})$, microwave $(4 \mathrm{~h})$, and directed ultrasound (6 $\min )$. This is where the intermolecular interactions (i.e., van der Waals interactions and hydrogen bonding) within the cellulose network have been disrupted. FTIR studies provided a clear indication that the chemical bonding throughout the substrate remained unchanged when compared with untreated wood waste. However, the surface morphology of the feedstock was found to be markedly different for each technology. For directed ultrasound, the once clearly defined channels begun to rupture, forming microfibrils. Ultimately, the effect of pretreatment technology benefitted the rate of mass loss for the cellulose and hemicellulose light volatile region $\left(\sim 400{ }^{\circ} \mathrm{C}\right.$, Figure 5$)$. This was most prolific for microwave $(4 \mathrm{~h})$ and directed ultrasound $(6 \mathrm{~min})$, the latter being the most energy efficient technique used (Figure 4 and Table 4). For directed ultrasound, there was also a clear reduction in char yield (decrease of 51\%) as compared with the parent wood waste. However, for the future of the energy 
production sector, from the augmented technologies investigated, directed ultrasound is the most promising to be scaled up for industrial scale biomass waste pretreatment. It is already applicable at scale in other industrial practices. As shown in this work, this enhanced technology had the highest performance rate based on the multiparameter assessment evaluation. In this assessment, it was found that microwave irradiation was very poor, with the exception of rapid S removal.

\section{ASSOCIATED CONTENT}

\section{SI Supporting Information}

The Supporting Information is available free of charge at https://pubs.acs.org/doi/10.1021/acssuschemeng.0c00351.

Additional graphs presenting ICP-OES and PXRD data over time as well as the method of $\mathrm{Crl}$ determination (PDF)

\section{AUTHOR INFORMATION}

\section{Corresponding Authors}

Martin J. Taylor - Energy and Environment Institute and B3 Challenge Group, Department of Chemical Engineering, University of Hull, Hull HU6 7RX, United Kingdom; 구 orcid.org/0000-0001-7966-6275; Email: Martin.Taylor@ hull.ac.uk

Vasiliki Skoulou - Energy and Environment Institute and B3 Challenge Group, Department of Chemical Engineering, University of Hull, Hull HU6 7RX, United Kingdom; ๑ orcid.org/0000-0001-6947-5360; Email: V.Skoulou@ hull.ac.uk

\section{Authors}

Hassan A. Alabdrabalameer - B3 Challenge Group, Department of Chemical Engineering, University of Hull, Hull HU6 7RX, United Kingdom

Apostolos K. Michopoulos - Energy and Environmental Design of Buildings Research Lab, University of Cyprus, 1678 Nicosia, Cyprus

Roberto Volpe - School of Engineering and Materials Science, Queen Mary University of London, London E1 4NS, United Kingdom; (i) orcid.org/0000-0002-8829-807X

Complete contact information is available at:

https://pubs.acs.org/10.1021/acssuschemeng.0c00351

\section{Notes}

The authors declare no competing financial interest.

\section{ACKNOWLEDGMENTS}

M.J.T. and V.S. acknowledge the EPSRC (EP/P034667/1) and funding through the THYME project (UKRI, Research England). We would like to thank Mr. Timothy Dunstan for this acquisition of HRSEM images and EDX data. We would also like to thank Mr. Sean Moore for the operation of the TGA.

\section{REFERENCES}

(1) Gielen, D.; Boshell, F.; Saygin, D.; Bazilian, M. D.; Wagner, N.; Gorini, R. The role of renewable energy in the global energy transformation. Energy Strategy Reviews 2019, 24, 38-50.

(2) Owusu, P. A.; Asumadu-Sarkodie, S. A review of renewable energy sources, sustainability issues and climate change mitigation. Cogent Engineering 2016, 3, 1-14.

(3) Lund, H. Renewable energy strategies for sustainable development. Energy 2007, 32 (6), 912-919.
(4) Taylor, M. J.; Alabdrabalameer, H. A.; Skoulou, V. Choosing Physical, Physicochemical and Chemical Methods of Pre-Treating Lignocellulosic Wastes to Repurpose into Solid Fuels. Sustainability 2019, 11, 3604.

(5) Sharif, A.; Raza, S. A.; Ozturk, I.; Afshan, S. The dynamic relationship of renewable and nonrenewable energy consumption with carbon emission: A global study with the application of heterogeneous panel estimations. Renewable Energy 2019, 133, 685-691.

(6) Foust, T. D.; Aden, A.; Dutta, A.; Phillips, S. An economic and environmental comparison of a biochemical and a thermochemical lignocellulosic ethanol conversion processes. Cellulose 2009, 16 (4), 547-565.

(7) Popp, J.; Lakner, Z.; Harangi-Rakos, M.; Fari, M. The effect of bioenergy expansion: Food, energy, and environment. Renewable Sustainable Energy Rev. 2014, 32, 559-578.

(8) Kersten, S. R. A.; Potic, B.; Prins, W.; Van Swaaij, W. P. M. Gasification of model compounds and wood in hot compressed water. Ind. Eng. Chem. Res. 2006, 45 (12), 4169-4177.

(9) Yong, T. L.-K.; Matsumura, Y. Catalytic Gasification of Poultry Manure and Eucalyptus Wood Mixture in Supercritical Water. Ind. Eng. Chem. Res. 2012, 51 (16), 5685-5690.

(10) Franco, C.; Pinto, F.; Gulyurtlu, I.; Cabrita, I. The study of reactions influencing the biomass steam gasification process. Fuel 2003, 82 (7), 835-842.

(11) Vonk, G.; Piriou, B.; Wolbert, D.; Cammarano, C.; Vaïtilingom, G. Analysis of pollutants in the product gas of a pilot scale downdraft gasifier fed with wood, or mixtures of wood and waste materials. Biomass Bioenergy 2019, 125, 139-150.

(12) Zhu, H. L.; Zhang, Y. S.; Materazzi, M.; Aranda, G.; Brett, D. J. L.; Shearing, P. R.; Manos, G. Co-gasification of beech-wood and polyethylene in a fluidized-bed reactor. Fuel Process. Technol. 2019, 190, 29-37.

(13) Aydin, E. S.; Yucel, O.; Sadikoglu, H. Experimental study on hydrogen-rich syngas production via gasification of pine cone particles and wood pellets in a fixed bed downdraft gasifier. Int. J. Hydrogen Energy 2019, 44 (32), 17389-17396.

(14) Skoulou, V.; Zabaniotou, A. Investigation of agricultural and animal wastes in Greece and their allocation to potential application for energy production. Renewable Sustainable Energy Rev. 2007, 11 (8), 1698-1719.

(15) Ren, Q.; Zhao, C.; Wu, X.; Liang, C.; Chen, X.; Shen, J.; Wang, $\mathrm{Z}$. Formation of NOx precursors during wheat straw pyrolysis and gasification with $\mathrm{O} 2$ and CO2. Fuel 2010, 89 (5), 1064-1069.

(16) Ubando, A. T.; Rivera, D. R. T.; Chen, W. H.; Culaba, A. B. A comprehensive review of life cycle assessment (LCA) of microalgal and lignocellulosic bioenergy products from thermochemical processes. Bioresour. Technol. 2019, 291, 121837.

(17) Kumar, P.; Barrett, D. M.; Delwiche, M. J.; Stroeve, P. Pulsed Electric Field Pretreatment of Switchgrass and Wood Chip Species for Biofuel Production. Ind. Eng. Chem. Res. 2011, 50 (19), 1099611001.

(18) Chang, A. C. C.; Chang, H.-F.; Lin, F.-J.; Lin, K.-H.; Chen, C.$\mathrm{H}$. Biomass gasification for hydrogen production. Int. J. Hydrogen Energy 2011, 36 (21), 14252-14260.

(19) Sano, T.; Miura, S.; Furusawa, H.; Kaneko, S.; Yoshida, T.; Nomura, T.; Ohara, S. Composition of inorganic elements and the leaching behavior of biomass combustion ashes discharged from wood pellet boilers in Japan. J. Wood Sci. 2013, 59 (4), 307-320.

(20) Arvelakis, S.; Sotiriou, C.; Moutsatsou, A.; Koukios, E. G. Prediction of the behaviour of biomass ash in fluidized bed combustors and gasifiers. J. Therm. Anal. Calorim. 1999, 56 (3), $1271-1278$

(21) Vamvuka, D.; Zografos, D.; Alevizos, G. Control methods for mitigating biomass ash-related problems in fluidized beds. Bioresour. Technol. 2008, 99 (9), 3534-44.

(22) Mahadevan, R.; Adhikari, S.; Shakya, R.; Wang, K.; Dayton, D.; Lehrich, M.; Taylor, S. E. Effect of Alkali and Alkaline Earth Metals on in-Situ Catalytic Fast Pyrolysis of Lignocellulosic Biomass: A Microreactor Study. Energy Fuels 2016, 30 (4), 3045-3056. 
(23) Fahmi, R.; Bridgwater, A. V.; Darvell, L. I.; Jones, J. M.; Yates, N.; Thain, S.; Donnison, I. S. The effect of alkali metals on combustion and pyrolysis of Lolium and Festuca grasses, switchgrass and willow. Fuel 2007, 86, 1560-1569.

(24) Berdugo Vilches, T.; Marinkovic, J.; Seemann, M.; Thunman, H. Comparing Active Bed Materials in a Dual Fluidized Bed Biomass Gasifier: Olivine, Bauxite, Quartz-Sand, and Ilmenite. Energy Fuels 2016, 30 (6), 4848-4857.

(25) Skoulou, V.; Zabaniotou, A. Fe catalysis for lignocellulosic biomass conversion to fuels and materials via thermochemical processes. Catal. Today 2012, 196 (1), 56-66.

(26) McKendry, P. Energy production from biomass (Part 3): Gasification technologies. Bioresour. Technol. 2002, 83 (1), 55-63.

(27) Arvelakis, S.; Vourliotis, P.; Kakaras, E.; Koukios, E. G. Effect of leaching on the ash behavior of wheat straw and olive residue during fluidized bed combustion. Biomass Bioenergy 2001, 20 (6), 459-470.

(28) Weerachanchai, P.; Horio, M.; Tangsathitkulchai, C. Effects of gasifying conditions and bed materials on fluidized bed steam gasification of wood biomass. Bioresour. Technol. 2009, 100 (3), 1419-27.

(29) Kumar, A.; Jones, D.; Hanna, M. Thermochemical Biomass Gasification: A Review of the Current Status of the Technology. Energies 2009, 2 (3), 556-581.

(30) Pecho, J.; Schildhauer, T. J.; Sturzenegger, M.; Biollaz, S.; Wokaun, A. Reactive bed materials for improved biomass gasification in a circulating fluidised bed reactor. Chem. Eng. Sci. 2008, 63 (9), $2465-2476$.

(31) Asadullah, M.; Miyazawa, T.; Ito, S.-i.; Kunimori, K.; Koyama, S.; Tomishige, K. A comparison of $\mathrm{Rh} / \mathrm{CeO} 2 / \mathrm{SiO} 2$ catalysts with steam reforming catalysts, dolomite and inert materials as bed materials in low throughput fluidized bed gasification systems. Biomass Bioenergy 2004, 26 (3), 269-279.

(32) Deng, L.; Zhang, T.; Che, D. Effect of water washing on fuel properties, pyrolysis and combustion characteristics, and ash fusibility of biomass. Fuel Process. Technol. 2013, 106, 712-720.

(33) Cen, K.; Zhang, J.; Ma, Z.; Chen, D.; Zhou, J.; Ma, H. Investigation of the relevance between biomass pyrolysis polygenerationand washing pretreatment under different severities Water, dilute acidsolution and aqueous phase bio-oil. Bioresour. Technol. 2019, 278, 26-33.

(34) Bettelheim, J.; Hann, W. W. An Investigation of Water Leaching of Some British Coals. J. Inst. Energy 1980, 53 (416), 103108.

(35) Muralidhara, H. S.; Venkateswar, R.; Chauhan, S. P. Leaching of Sodium and Chlorine from Coals. Sep. Sci. Technol. 1986, 21 (67), 625-642.

(36) Jensen, P. A.; Sander, B.; Dam-Johansen, K. Removal of K and $\mathrm{Cl}$ by leaching of straw char. Biomass Bioenergy 2001, 20 (6), 447457.

(37) Davidsson, K. O.; Korsgren, J. G.; Pettersson, J. B. C.; Jaglid, U. The effects of fuel washing techniques on alkali release from biomass. Fuel 2002, 81 (2), 137-142.

(38) Al-Harahsheh, M.; Kingman, S. W. Microwave-assisted leaching-a review. Hydrometallurgy 2004, 73 (3-4), 189-203.

(39) Luque-García, J. L.; Luque de Castro, M. D. Ultrasound: a powerful tool for leaching. TrAC, Trends Anal. Chem. 2003, 22 (1), $41-47$.

(40) Fromm, J. Wood formation of trees in relation to potassium and calcium nutrition. Tree Physiol. 2010, 30 (9), 1140-7.

(41) Vaskalis, I.; Skoulou, V.; Stavropoulos, G.; Zabaniotou, A. Towards Circular Economy Solutions for The Management of Rice Processing Residues to Bioenergy via Gasification. Sustainability 2019, 11 (22), 6433.

(42) Wang, Z.; McDonald, A. G.; Westerhof, R. J. M.; Kersten, S. R. A.; Cuba-Torres, C. M.; Ha, S.; Pecha, B.; Garcia-Perez, M. Effect of cellulose crystallinity on the formation of a liquid intermediate and on product distribution during pyrolysis. J. Anal. Appl. Pyrolysis 2013, $100,56-66$.
(43) Kim, S. H.; Lee, C. M.; Kafle, K. Characterization of crystalline cellulose in biomass: Basic principles, applications, and limitations of XRD, NMR, IR, Raman, and SFG. Korean J. Chem. Eng. 2013, 30 (12), 2127-2141.

(44) Segal, L.; Creely, J. J.; Martin, A. E.; Conrad, C. M. An Empirical Method for Estimating the Degree of Crystallinity of Native Cellulose Using the X-Ray Diffractometer. Text. Res. J. 1959, 29 (10), 786-794.

(45) Park, S.; Baker, J. O.; Himmel, M. E.; Parilla, P. A.; Johnson, D. $\mathrm{K}$. Cellulose crystallinity index: measurement techniques and their impact on interpreting cellulase performance. Biotechnol. Biofuels 2010, 3, 10 .

(46) Kubo, S.; Kadla, J. F. Hydrogen bonding in lignin: a Fourier transform infrared model compound study. Biomacromolecules 2005, 6 (5), 2815-21.

(47) Xu, F.; Yu, J.; Tesso, T.; Dowell, F.; Wang, D. Qualitative and quantitative analysis of lignocellulosic biomass using infrared techniques: A mini-review. Appl. Energy 2013, 104, 801-809.

(48) Fabičovicová, K.; Lucas, M.; Claus, P. From microcrystalline cellulose to hard- and softwood-based feedstocks: their hydrogenolysis to polyols over a highly efficient ruthenium-tungsten catalyst. Green Chem. 2015, 17 (5), 3075-3083.

(49) Sills, D. L.; Gossett, J. M. Using FTIR to predict saccharification from enzymatic hydrolysis of alkali-pretreated biomasses. Biotechnol. Bioeng. 2012, 109 (2), 353-62.

(50) Saito, K.; Horikawa, Y.; Sugiyama, J.; Watanabe, T.; Kobayashi, Y.; Takabe, K. Effect of thermochemical pretreatment on lignin alteration and cell wall microstructural degradation in Eucalyptus globulus: comparison of acid, alkali, and water pretreatments. J. Wood Sci. 2016, 62 (3), 276-284.

(51) Loy, A. C. M.; Gan, D. K. W.; Yusup, S.; Chin, B. L. F.; Lam, M. K.; Shahbaz, M.; Unrean, P.; Acda, M. N.; Rianawati, E. Thermogravimetric kinetic modelling of in-situ catalytic pyrolytic conversion of rice husk to bioenergy using rice hull ash catalyst. Bioresour. Technol. 2018, 261, 213-222. 